\title{
Feline Affinities Between E.T.A. Hoffmann's The Life and Opinions of the Tomcat Murr and Natsume Sōseki's I Am a Cat
}

\author{
Val Scullion ${ }^{1} \&$ Marion Treby ${ }^{2}$ \\ ${ }^{1}$ Independent scholar, Buckden, United Kingdom \\ ${ }^{2}$ Independent scholar, Newmarket, United Kingdom \\ Correspondence: Val Scullion, 51, Park Road, Buckden, St Neots, Cambs, PE19 5SL, United Kingdom. E-mail: \\ pjvj51@btinternet.com
}

Received: January 25, 2021 Accepted: March 15, 2021 Online Published: March 23, 2021

doi:10.5539/ells.v11n2p1 URL: https://doi.org/10.5539/ells.v11n2p1

\begin{abstract}
Natsume Sōseki (1867-1916) was an eclectic writer and voracious reader during a historical period when western literary influence flourished in Japan. This article hypothesizes that the German novel, The Life and Opinions of Tomcat Murr (1819-1821), by E.T.A. Hoffmann (1776-1822), is as strong a formative influence in terms of structure and satirical perspective on Sōseki's novel, I Am a Cat (1905-1907), as other satiric contenders. It pursues this argument by examining correlations between these two polyphonic novels which mix many registers and discourses in a similar way. Biographical, historical and literary analysis underpins this comparison.
\end{abstract}

Keywords: Hoffmann, Sōseki, satiric, grotesque, Tomcat Murr, cat-narrator

\section{Introduction}

There are many affinities between the German novel, The Life and Opinions of the Tomcat Murr (Lebensansichten des Katers Murr, 1819-1821) by E.T.A. Hoffmann (1776-1822), and the Japanese novel, I Am a Cat (Wagahai wa Neko de Aru, 1905-1907) by Natsume Sōseki (1867-1916). Nathan states that Hoffmann's novel was introduced by Teinosuke Fujishiro "as early as 1906" to Japanese readers and to Natsume Sōseki himself (Nathan, 2018, p. 92) (Note 1). While acknowledging that Sōseki's cat-narrator comments on Tomcat Murr in the third and last volume of I Am a Cat, he argues that the two novels, "apart from the feline narrators ... have little in common" (ibid., p. 93). Keene gives examples from various Japanese critics, including Osamu Hamano in 1934 and Rokurō Yoshida in 1968, who compare the two novels in question, and list no less than a dozen points of resemblances which show Hoffmann's influence. However, Keene also argues that "most of the parallels are unconvincing, and the remainder can be explained as natural developments from the initial conception of having a cat-narrator" (Keene, 1998, p. 350, note 20). He maintains, and Nathan also concurs with the first claim of the following two, that Laurence Sterne's The Life and Opinions of Tristram Shandy, Gentleman (1759-1767), and Jonathan Swift's Gulliver's Travels (1726) are far better candidates to account for western literary influence on Sōseki's novel. While we agree that the satirists, Sterne and Swift, shape Sōseki's writing (as they also influence Hoffmann's) (Note 2), we do not align entirely with Nathan and Keene's conclusions. Through Marcus's cogent biography of Sōseki, we are enabled to point out that he (Sōseki) knew about Hoffmann's oeuvre even as a student, and definitely before residing in England during his academic scholarship from 1900-1903 (Marcus, 2009, p. 165).

\section{Literary and Historical Contexts}

Absolute proof that Sōseki knew of Hoffmann's novel occurs in the last pages of Volume Three of I Am a Cat (1907), immediately before his cat-narrator's death. This unnamed cat-narrator describes seeing a spectral "German mog called Kater Murr" who "started sounding off in a very high falutin' manner on my own special subject." Sōseki's cat observes "if such a feline culture-hero was already demonstrating superior cat skills so long as a century ago, perhaps a good-for-nothing specimen like me has already outlived its purpose and should no more delay its retirement into nothingness" (Sōseki, 2002, p. 457). Keene argues: "nothing suggests that Sōseki knew Hoffmann's work while writing the earlier sections" (Keene, 1998, p. 350, note 20). Given Sōseki's immersion in western literature since his student days, and the extent of his academic scholarship, we disagree 
with Keene.

The opening up of Japan and its adoption of western values and mores after the arrival of Commodore Matthew Perry's American steamships in 1853, brought about varying degrees of welcome and hostility from the very beginning. Sōseki's own fear for the loss of Japanese culture began in his youth and strengthened as he aged (Note 3). Yet he read his way through swathes of the European literary canon, and later introduced western literature and literary theory into Japan (Note 4). His birth and death dates (1867-1916) are almost exactly coterminous with the Meiji period under the reign of Emperor Mutsuhito (1867-1912), during which time Japan was transformed into a modern, industrialized and imperial nation on the model of western powers. Until 1899, when "The Constitution of the Empire of Japan" was ratified with the establishment of the Imperial Diet (legislative government), many German advisors worked in Japan (oyatoi gaikokujin-hired foreigners), particularly as experts in systems of law. Many Japanese envoys were also sent to Germany, Britain and the United States. Consequently, students, professionals, educationalists, medics, scientists and politicians spread western ideas on their return.

In addition to revolutionizing Japan's industrial and naval hardware, new western technologies transformed Japanese art and media. For example, the dissemination of news through wood-block prints and handbills gave way to lithography which allowed the transfer of illustrations and photographs to the printed page. This facilitated large circulations (Note 5). As education for all spread, so newspapers, journals and magazines flourished and reached a broad audience. These included popular magazines for boys, girls and women. One such monthly girls' magazine called Foundation of the Nation (Kuni no Motoi), published between 1889 and 1890, was suppressed by the Imperial Diet for being too westernized. Short-lived though it was, it contained the first, incomplete translation of Mary Shelley's Frankenstein (Nakagawa, 2014) (Note 6). Listed in the order they were published, translations of works by Edward Bulwer-Lytton, Fyodor Dostoyevsky, William Wordsworth, Robert Burns and Shakespeare, amongst others, appeared from the 1870s onwards (Note 7). Charlotte Brontë's Jane Eyre (1847), which explores female identity, reached Japan in the late-nineteenth century (Note 8). By 1905, translations of the French Parnassian and Symbolist poets also became available in Japan (Note 9). Émile Zola's work was recognized for its theories of Naturalism, and debated by Meiji intellectuals, including Mori Ōgai (1862-1922) (Note 10). Mori Ōgai (pen name of Mori Rintarō) was the first to introduce German literature widely to Japanese readers. Sent as a young military surgeon to study western methods of hygiene, he lived in Dresden, Munich and Berlin from 1884 to 1888, and avidly read English and German literature during his stay. On his return to Tokyo in 1889, Mori Ōgai founded the literary magazine, The Weir, and several other journals in which he published original and translated literature, and literary criticism (Note 11). He was one of the first to acquaint his Japanese audience with the work of Goethe, Gottholdt Lessing, Heinrich von Kleist, Heinrich Heine and Hoffmann (Rimer, 1975, pp. 24, 36). During March to July 1889, he published his own translation, Tama o Idaite Tsumi Ari, of Hoffmann's story, Mademoiselle de Scuderi (1820), introducing him as a forerunner of Edgar Allan Poe. Both Aeba Kōson (1855-1922) and Uchida Roan (1868-1929) translated Poe's The Black Cat, in 1887 and 1893 respectively, and in 1896-1897 Poe's The Pit and the Pendulum appeared as Kan-Ippatsu (Nakai, 1978, p. 383) (Note 12). Mori Ōgai's poetry magazine Vestiges, dating, like The Weir, from 1889, included translations of many major poets such as Byron and Thomas Gray, together with the traditional Japanese poetic forms haiku and waka. Vestiges also featured Mori Ōgai's translation of the poem, "The Lost Star of my Love," from Hoffmann's tale Master Martin the Cooper of Nuremberg and his Apprentices (1819) (ibid.). Thus, Hoffmann's work was part of the influx of translated, abridged and adapted western literature to reach Japan as the nineteenth century gave way to the twentieth. All these publications are symptomatic of a growing appetite for European literature. Whether read in depth or not, western literary works were readily available to the Japanese reading public.

Given this historical and literary context, and that Soseki was an insatiable reader and buyer of books, it is not surprising that he came across Hoffmann's work as a student through his university tutor, the German Professor Raphael von Koeber (1848-1923). Sōseki's "literary portrait" of Koeber, written in 1911, describes him retrospectively as "an avid reader of Poe and E.T.A. Hoffmann" (Marcus, 2009, p. 165) (Note 13). That Sōseki wrote a second piece about Koeber to commemorate the latter's planned departure from Japan, prevented by the First World War, is testament to the bond between him and his old teacher, which lasted for nearly twenty years. Sōseki also became familiar with Hoffmann and other German writers through association with his fellow Monbushō (Ministry of Education) scholar and friend, Teisuke Fujishiro (1868-1927). In September 1900, Fujishiro and Sōseki voyaged from Japan for several weeks together on the Preussen to begin their periods of study in the west, with Fujishiro bound for Germany and Sōseki for London. They continued to correspond with each other, and, when he had completed his studies in Germany and travelled to London, Fujishiro became 
Sōseki's "companion" (ibid., p. 216). They would therefore have had the opportunity to discuss the literature Fujishiro had encountered in Germany. Later, they were both professors of literature at Tokyo University (ibid., p. 215, note 46). Nathan describes Fujishiro as "the father of German literature studies in Japan", who introduced Japanese readers to Hoffmann's Tomcat Murr and identified similarities and differences between it and Sōseki's novel (Nathan, 2018, p. 92). Despite this, Nathan downplays Hoffmann's novel, attributing dominant influences on I Am a Cat elsewhere.

\section{Literary Structures and Engagement with Contemporary Discourses}

The unusual structure of Tomcat Murr splices together Murr's autobiographical novel with the biographical musical adventures of Kreisler, one written on the reverse side of the other according to the fiction of the narration. The two narratives, as indicated by the full title of the novel: The Life and Opinions of Tomcat Murr: Together with a Fragmentary Biography of Conductor Johannes Kreisler on Random Sheets of Waste Paper, are printed with the front and back of the sheets alternating and running non-chronologically. Hoffmann, as author and self-designated editor, apologizes for the novel going into print in its entirety, including Kreisler's reverse-sided biography (Hoffmann, 2016, p. 1). In the separate episodes of his first-person narrative, Murr boasts that he has read and written many books and poems and that much of his work has been published, the text of the novel being fictional proof of his claim. Furthermore, fictional human characters in the novel believe him to be a gifted author. The first Foreword of the novel, signed by Hoffmann himself, explains how a friend gave him the manuscript written by Murr which he submitted to his own real-life publisher, Ferdinand Dümmler. In keeping with this conceit, Herr Dümmler is reported to have said that "although he had never numbered a cat among his authors before ... he was willing to make the attempt" (ibid.). It is significant that the novel's title, various Forewords (two of which, according to the fiction, are penned by Murr), and the Preface all refer to the eponymous cat, rather than to Kreisler. These witty devices should discourage any marginalization of Murr, yet criticism tends to focus on Kreisler. For example, Meyer regards Murr's autobiography as having merely a "contrastive function" (Meyer, 1968, p. 126). We foreground the equal importance of Hoffmann's tomcat and Kreisler. Hoffmann's novel, by including many discourses, such as the use of various narrators, a high incidence of dialogue, poems, songs, prefaces and editors' comments, can justifiably be described as polyphonic (Note 14).

The entanglement of Tomcat Murr's autobiography with Kreisler's biography in Tomcat Murr is a structural and ironic device which questions the stability of meanings in both sections. As Clason succinctly puts it: "Murr wants to live well, but produces bad art, while Kreisler wishes to create true art, but cannot live well .... The novel's intriguing structure embraces both corporal and intellectual principles" (Clason, 1992, p. 500). Thus, the form of the novel expresses the duality of spirit and body, imagination and materiality, and the romantic, aesthetic dilemma of attempting to reconcile artistic inner yearning with the need to live in the world. The comedy of Murr's autobiography is that he defaults invariably to material need and visceral appetite while still believing himself to be "the glowing comet, the celestial meteor passing prophetically in great glory through the world" (Hoffmann, 2016, p. 116). While Kreisler's genuine musical vocation renders him a foolish, comic, but well-meaning social misfit, Murr's gross self-deception that he is a literary genius allows Hoffmann to launch satiric barbs against artistic charlatans (Note 15).

Sōseki's novel, with its single plot, has a simpler narrative structure than Tomcat Murr. It began life as a short story, read aloud to members at a meeting of the Yamakai reading group organized by his colleague, Kyoshi Takahama (1874-1959), editor of the literary magazine Hototogisu (Cuckoo). Takahama published I Am a Cat in the January 1905 issue and, by the end of that year, its subsequent issues featured five further chapters. Sōseki added five more "Installments" (sic), bringing his cat's first-person narrative to its close in the issue of August 1906. In 1905, the first five chapters, published together in one volume, proved so popular that the first printing sold out in twenty days and Sōseki's university students nicknamed him "Professor Cat" (Nathan, 2018, p. 91). This set the publishing pattern of all his novels which, unlike I Am a Cat, were printed in daily instalments in the Asahi Shimbun newspaper. Sōseki held the post of writer in residence at this newspaper from March 1907 until his death in 1916.

Like Tomcat Murr, Sōseki's fictional cat, (hereafter known as Neko, the Japanese word for "cat"), can read and write. In first-person narrative, Neko explicitly tells his readers "these close written pages, which the more superficial minds amongst you have seen as nothing better than a tiresome spate of trivial chit-chat, shall suddenly reveal themselves as containing weighty wisdom, edifying homilies, guidance for you all" (Sōseki, 2002, p. 295). As conceited about his intellectual abilities as Murr, Neko is thoroughly convinced of his own infallibility. He believes that his powerful tail encompasses "... not only the power of God, Buddha, Confucius, Love, and even Death, but (is) also an infallible panacea for all ills that could bewitch the entire human race" (ibid., p. 104). However, Neko's antics as he chases his tail, which he calls the "Gracious Deity," (ibid., p. 105), 
exemplify instinctive, ordinary cat behaviour to which he ascribes metaphysical powers. In common with Murr, Neko observes the behaviour and records the conversation of human beings around him, often making satirical comments about his master, the schoolteacher Kushami, and Kushami's academic associates: the aesthetician and raconteur Meitei, the physics student Kangetsu Mizushima, and the poet Tofu Ochi. Yagi Dokusen, a scholar of Zen Buddhist philosophy, a late-comer to the coterie, is also the object of the cat's satire. Neko reveals himself to have far more insight than any of the humans he meets, observing justifiably that they are "non-productive intellectuals" and "hermits in a peaceful reign" (ibid., p. 66).

These individuals represent a new social group which emerged in Japan between the Sino-Japanese and Russo-Japanese wars of 1885 and 1904-1905 (Katō, 1997, p. 257). Sōseki, refracted through the voice of Neko, ridicules such groups. Given that Sōseki was the leading scholar of English literature in Meiji Japan (Marcus, 2009, p. 2), I Am a Cat may thus be read as a mockery of his own circle of late Meiji intellectuals; and its group leader, Kushami, as a satiric portrait of school teachers of the time. He lacks the nobility of character and high standard of professional ethics then expected of teachers (Note 16). Far from seeing teaching as a "sacred profession" (Jenkins, 2014, p. 20), Kushami is so disillusioned and ineffective that he does not even recognise Lancelot Yore, one of his pupils who begs for his help. Sōseki's cat-narrator comments drily, "my master is unpopular, and hardly a single schoolboy ever comes near him" (Sōseki, 2002, p. 386). Kushami may also be a satiric self-portrait of Sōseki. Fujii, however, argues that I Am a Cat is much more than a self-referential satire. Its "dialogic structure", he maintains, is a "form of protest against genbun'ichi" (Fujii, 1989, p. 556), the new, more westernized form of the Japanese language which the government was then keen to introduce (Note 17). I Am a Cat, Fujii continues, therefore embodies Sōseki's concerns about the future of the Japanese language. Treat suggests that Sōseki's position regarding this state-sponsored adoption of genbun 'ichi is more nuanced than one of protest, and that, by foregrounding orality within a written text at a time when Japanese culture was moving from oral to textual forms, Sōseki, through Neko, is participating in a wider linguistic debate. It is particularly apposite, therefore, that the original story of I Am a Cat was read aloud, and only later converted into text.

In entering this current cultural debate, Sōseki echoes Hoffmann's engagement with contemporary issues surrounding, in his case, German philology. Tomcat Murr is so proud of his ability to learn easily the language of Poodlish, as spoken by his friend Ponto, the poodle, that he writes a book about it. Murr's egotistical remarks can be read ironically as referring to the contemporary interest in the study of Sanskrit and the current debate as to whether one can learn a foreign language to the same standard as an indigenous speaker. Murr also pontificates about his owner's, Master Abraham's, advice to the Lord Marshal in the court of Sieghartsweiler that this courtier's verbal affectation, which peppers his speech with rote-learnt French phrases, renders him ridiculous (ibid., pp. 39-40). In comparison, Sōseki's novel not only foregrounds spoken language in Neko's discourse, but also exemplifies it in "rakugo, popular songs, epigrams, and a host of other forms with strong traces of orality", which together bring some collective unity to the novel (Fujii, 1989, p. 562). Using Neko's ability to eavesdrop and comment to the reader on what he hears, Sōseki conveys orality within textuality. Poems and stories read aloud and discussed by his master's friends, snippets from a lecture, epigrams from Zen philosophy, and speeches, are amongst its plurality of discourses. The result is a prose text which Treat describes as "carnivalesque", a device which embraces the concepts of farce, bathos, parody, irony and satire (Treat, 2018, p. 95). Such devices and varied registers jostling side by side merit our description of Sōseki's novel as polyphonic.

\section{Four Cats-Real and Imagined}

In real life, Hoffmann and Sōseki both owned cats, which became models for their fictional cat-narrators. Whilst Hoffmann affectionately named his pet both in reality and in his fiction, Sōseki did not, indicating the authors' differing approaches to their cats. In late November 1821, just before he finished writing Volume Two of Tomcat Murr, Hoffmann announced in a letter to friends, the death of his beloved cat, named Kater (Tomcat) Murr. His praise of Kater Murr's "promising life" is ironic in tone, but sorrow at his loss is genuine (Sahlin, 1977, p. 315). At the same time, Hoffmann's surrogate, the fictional editor of his novel, also announces the death of Tomcat Murr. His initial ironic hyperbole gives way to a more ambivalent tone in such phrases as "peace be to your ashes" (Hoffmann, 2016, p. 279). The postscript also ends with the editor's promise for next Easter's book fair of a third volume, containing further fragments of Murr's posthumous writing. As we now know, the third volume did not appear. Hoffman's own death from spinal paralysis in June 1822 prevented completion. Sōseki's autobiographical vignette, "The Cat's Grave" (1909) gives an account of the death of his cat on whom Neko was based. Whilst Sōseki may not have been as attached to the stray kitten which found its way into the Natsume household as Hoffmann was to Murr, nevertheless, after Neko's death, the family erected a grave marker; Sōseki composed a short poem in the cat's memory; and his wife and children treated Neko's grave almost as a shrine (Sōseki, 2015, p. 64). The death of these family pets is not relevant to literary transmission, but might explain to 
a degree some of the affection, in the respective novels, of Master Abraham and Master Kushami for their fictional cats (Sōseki, 2002, p. 78). Both feline protagonists fulfil, albeit ironically, the role in the fairytale tradition of the cat as helper, companion, and philosopher (Note 18). Indicatively, a Japanese translation of Charles Perrault's fairy tale, Puss-in Boots, was published in a collection of French fairy tales in 1896 (Otaki, 2014, ch. 1, sect. 2). Thus, a western version of feline relationships with humans, as in Puss-in-Boots, Dick Whittington and the magic-servant cat or witches' familiar, had migrated to the newly-opened-up Japan by that time. The idea of a philosophical cat is completely at odds with the Japanese folklore of cats as frequently presented in kabuki plays and wood-block prints. These supernatural cats, or kaibyō, develop from domestic cats as they grow up, and are invariably monstrous, horrific and vicious (Note 19). By denying Neko any such attributes, Sōseki aligns his fictional cat with the western, rather than the Japanese, tradition.

Both Hoffmann's fictional Murr and Sōseki's Neko have a close attachment to their masters, albeit one mixed with love of the creature comforts they are provided with. Master Abraham, a magus, scholar and maker of fireworks, resident at the petty German royal court of Sieghartsweiler, saves Murr from drowning as a kitten. He is unfailingly kind and patient with his mischievous pet, rescuing him from a skylight when trapped by fire (Hoffmann, 2016, p. 92), playing with him (ibid. p. 142), brushing him clean after he hides in the stove (ibid., p. 195) and nursing him through fever (ibid., p. 265). Lastly, when Master Abraham has to leave Sieghartsweiler, he arranges for Murr to live with his protégé, the musician Johannes Kreisler. Sōseki's master, Kushami, is less solicitous of Neko than Master Abraham is of Murr, but his attitude to his feline companion is markedly different from others in the household. Initially, Neko is "terribly unpopular with everyone except the master", whom he refers to as "the man who had taken me in" and "fed me" (Soseki, 2002, pp. 5, 256). The cat's obsession with food, and the observation of Kushami's friend, Meitei, that Neko has become "chubby" (ibid., p. 74) confirm his unusual status in Japan as a pet, rather than a ratter. Neko forgives his master's indolence; his failure to become a successful academic; and even his critical attitude toward his wife (ibid., pp. 131, 167), because, at heart, Neko sees him as kind. He shows his gratitude and loyalty to Kushami by spying on his neighbours, the self-seeking, materialistic Kanedas, who criticize and discredit him (ibid., p. 119). Neko also purposely sits on a cushion intended for a visitor whom he knows is deceiving his master (ibid., p. 133). When the latter disregards the advice of Tatara Sampei, the family's erstwhile houseboy, to "get rid of" Neko because he is idle and has never caught a rat (ibid., p. 171), the cat's intelligent response is to exercise and attempt to catch rats (ibid., pp. 225, 183-186). Even when Kushami "whacks" Neko's head to elicit a miaow, the latter insists that his action is "guileless and dim" rather than "mean". Kushami's unsuccessful attempts at Zen meditation elicit Neko's irritation with his master's "dullness of ... brain" (ibid., pp. 259, 312, 349). In comparison with the cat and his master in Hoffmann's Tomcat Murr, the bond between Sōseki's Neko and Kushami weakens in the later stages of the narrative, and, commensurately, Neko becomes increasingly skeptical and purposeless.

\section{Shared Literary Legacies}

According to critical consensus, Hoffmann and Sōseki share a detailed knowledge of Sterne's fiction; Sōseki, coming later in history, acknowledges both Sterne and Hoffmann as precursors. The extant two volumes of Hoffmann's The Life and Opinions of Tomcat Murr clearly owe a debt to the title and structure of Sterne's The Life and Opinions of Tristram Shandy, Gentleman. Hoffmann refers directly to Tristram Shandy's digressive narrative shape through Sterne's character, Corporal Trim, by drawing Corporal Trim's waving flourish in the air with his stick, and by copying Tristram Shandy's illustrations of looping, irregular lines to represent plot lines (Hoffmann, vol. 1, p. 781; Sterne, 2009, pp. 379, 490). The Preface, Forewords and complex plotting of Tomcat Murr make it immediately clear that Hoffmann is sympathetic to Sterne's writing practices. Sōseki's detailed knowledge of Sterne is apparent in his seminal article on Tristram Shandy (1897) (Note 20), while his own novel, described as "writing 'without a head or a tail, a creature like a sea slug", replicates its structure (Treat, 2018, p. 77). Echoing the implied feline pomposity of Hoffmann's novel title, Sōseki's title I Am a Cat, in Japanese grammar (which cannot be translated literally), is suggestive of upper-class arrogance (Note 21).

A recurring theme of Hoffmann, Sterne and Sōseki's novels is the grotesqueness of bodies. Hoffman is fully informed about the aesthetics of the grotesque. For example, the Foreword to his first collection, Fantasy Pieces in the Style of Callot (1814), registers his desire to model the characters, themes and structure of his writing on the grotesque illustrations of French engraver, Jacques Callot. He confesses he could not get enough of Callot's hybrid forms, which "emerge beside each other, even within each other", thus combining the fantastic with everyday life (Hoffmann, 1993a, p. 17). The style of the grotesque, featuring incongruous fusions of the ludicrous and the fearsome, or the living and the mechanical, recurs throughout his work. In Master Flea (1822), his final story, an adversary who recognized himself in the comic grotesque character, Knarrpanti, took Hoffmann to court for libel. Hoffmann dictated his defense from his deathbed, denying the charge and quoting 
from Karl Flögel's History of Grotesque Humor (1788), to assert the importance of laughter (Sahlin, 1977, p. 324) (Note 22). In 1827, Walter Scott described Hoffmann, in English translation, as the "first distinguished artist who exhibited the fantastic or supernatural grotesque in his compositions", which comprised "the most strange and complicated monsters" (Scott, 1827, p. 81). Scott favors the historical authenticity of his story, The Entail (1817), in comparison with the grotesqueries of The Sandman (1816), and states that, as a German Romantic, Hoffmann's "taste and temperament directed him too strongly to the grotesque and the fantastic" (ibid., p. 93). Despite Scott's personal judgement, which imputes the literary results of Hoffmann's "overheated imagination" to excessive drinking and smoking (ibid., p. 82), thus criticizing the author rather than his tales, the grotesque is undeniably a hallmark of Hoffmann's writing. Kayser, in line with critical consensus, argues that Hoffmann's use of the grotesque, together with Scott's essay, shaped the work of Edgar Allan Poe (Kayser, 1963 , pp. 76-77). It is significant, then, that Poe's The Black Cat and The Pit and the Pendulum were published in Japanese translation in 1887 and 1896-1897 respectively. Furthermore, Mori Ōgai, when he published his Japanese translation of Hoffmann's Mademoiselle de Scuderi in 1889, introduced him as a forerunner of Edgar Allan Poe (see Section 2, para. 3). Lippit pertinently explores Sōseki's essays on Poe, commenting on "the affinity he felt for the world of Poe" (Lippit, 1977, p. 30). In short, migration of literary modes of writing, including the grotesque, spreads by various routes, Hoffmannesque and otherwise, and so shapes Sōseki's prose fiction.

Burwick's analysis of the grotesque argues that the body is "rendered grotesque because of the way it is perceived" (Burwick, 1987, p. 13) (Note 23). Thus, cultural models of beauty or monstrosity influence received opinion, but personal perceptions may not align therewith. In general, the grotesque is an ill-sorted assemblage of incongruous, distorted or deformed parts, but the eye of the beholder, or, in fiction, the perception of characters or narrators, may override generalized interpretation. If Tomcat Murr's front cover reproduces Hoffmann's original drawing for it, then the impact of Hoffmann's preoccupation with physical grotesqueness is immediately apparent. This vignette depicts Murr writing, seated at a desk on a roof, dressed in a toga. The drawing mirrors musician Kreisler's comment in the verbal text that Murr has "the authoritative look of a Greek philosopher" (Hoffmann, 2016, p. 16). Clason comments: “(d)espite its grotesqueness, the drawing expresses Murr's self-estimation as a model of felinity ... in the same manner that the classical authors of Greek or Roman antiquity served as cultural prototypes for later eras" (Clason, 1992, p. 494). Clason goes on to analyse the grotesque figures in the arabesque border of the vignette, with which Hoffmann surrounds all four front and back covers that he drew for his two-volume novel (ibid., pp. 501-502). Furthermore, Murr's perception of his own feline beauty is distorted when seen from the point of view of the poodle, Scaramouche. Scaramouche concedes that Murr is allowed to be friends with his nephew, Ponto, in private, but must not join a gathering of poodles "because you aren't fit for such society and never could be, if only because your small ears betray your vulgar origins ... and would be regarded as most improper by all right-minded, large-eared poodles" (Hoffmann, 2016, p. 80). Perceptions of what are suitably large or small ears in relation to the face as a whole, therefore, stem from individualized views of beauty and ugliness.

Sōseki borrows from both Hoffmann and Sterne with regard to grotesque members of the body. The nose in particular engrosses characters in I Am a Cat, infusing the grotesque with the comic. Neko watches Kushami wipe his "nose-greased fingertip" on his blotter, ironically calling it one of his "charming little ways" (Soseki, 2002, p. 316). Bitten on the nose by a rat, Zen philosopher, Yagi Dokusen, immediately abandons his belief that Buddhist spiritual enlightenment places him above "mundane matters". Dokusen, fearing for his life, pleads with Meitei to "do something", whereupon Meitei smears the bite with a paste made from boiled rice grains, which he passes off as a rare Indian ointment (ibid., p. 336). Furthermore, Neko reports that when Meitei and Mizushima ridicule the enormous nose of Kushami's neighbor, Mrs Kaneda, Meitei makes explicit reference to Sterne's disquisition on noses in Tristram Shandy, calling it an "interesting treatment of the subject" (ibid., p. 146). According to Aldridge, Mrs Kaneda, nicknamed Madam Conk, and Mrs Kushami are "parallel to" the grotesque pedants Phutatorius and Kysarcius in Tristram Shandy (Aldridge, 2008, p. 661; Sterne, 2009, pp. 261-262). Jacobowitz also examines "the comic disquisition on the nose", the "nasal humor" and the use of Sneaze as Kushami's nickname in I Am a Cat in relation to Sterne's novel (Jacobowitz, 2009, pp. 52, 50). Grotesque genital humor accompanies these nasal jokes. Phutatorius, for example, manages to burn his private parts by dropping a hot chestnut into his open flies and Tristram, while urinating out of a sash window, is almost castrated by its fall (Sterne, 2009, p. 301) (Note 24). Yet, despite Sōseki echoing Sterne's preoccupation with the grotesque, there is a notable difference in narrative stance. Sterne's narrator throughout is the eponymous Tristram Shandy; there is not the thinnest whisker of a cat anywhere in his adventures. By contrast, Hoffmann and Sōseki refract their presentation of human antics through the different perspectives and first-person narration of cats. 
Sōseki's presentation of a Japanese bathhouse through his cat-narrator's unique gaze owes as much to Hoffmann's satiric narrative stance as to Sterne's use of the grotesque. Neko's irregular entry by the back door confronts him with a pile of bathhouse fuel. He deduces wrongly that the bathers within have been "apparently reduced to munching lumps of coal" (Sōseki, 2002, p. 241). Leaping up to survey them from above through steamed glass and "foggy veils" of mist rewards Neko with "the crass spectacularity" of human nakedness, which, in his mind, confirms their inferiority to cats (ibid., p. 243). One man's back displays a vast, but incomplete, tattoo depicting the heroic swordsman, Iwami Jūtarō, while another's spine is exposed "like knotted bamboo" and oozes pus as he "steams his crotch" (ibid., p. 252). Kushami's blurred head is "quashed, parboiled and poppy-red"; another's resembles a "haggard cucumber"; another's a "trampled pudding" (ibid., p. 253). "Horribly hairy legs and horrible, hairless things" become entangled as bathers climb out to robe themselves (ibid., p. 256).

Neko's unusual vantage point and the shocking revelation of human nakedness exemplify the grotesque, while his extended account of the rigmarole of speech emerging from the mouths of the bathers is potently satiric. Murr makes similar observations on the inanity of human conversation from a unique viewpoint when enclosed in his basket or hiding in his master's stove (Hoffmann, 2016, p. 192). In addition, it is significant that Neko's encounter with the grotesqueness of the bathhouse, alongside innumerable other encounters with the world around him, occurs in Volume Two of I Am a Cat. Thus, the cat's perspective, which strongly suggests a lineage back to Hoffmann, permeates all three volumes. We therefore disagree with Keene, who argues that Neko's dialogue with Murr at the very end of the novel is merely an expedient afterthought which allowed Sōseki to bring his serialization of I Am a Cat in Hototogisu to a close (Keene, 1998, p. 350, note 20).

\section{Autobiographies of Tomcat Murr and Neko}

The adventures of both felines comprise a series of scrapes. Murr becomes drunk, has romantic liaisons, is chased by dogs, wounded by bigger cats, and pelted with bricks and insults for caterwauling. Similarly, Neko becomes drunk, and falls in love with Tortoiseshell, a beautiful, high-class cat. Likewise, he is intimidated by a huge "rough customer" of a cat, named Rickshaw Blacky (Sōseki, 2002, p. 10). Endangered by rats, endemic in Tokyo while I Am a Cat was serialized, Neko also finds himself fearing for his life (ibid., p. 185). Much of the comedy of both autobiographies stems from the juxtaposition of farce and deluded self-praise. Throughout his life, Murr sustains an unquestioning belief in himself as a true genius, enjoys flattery, and expects young tomcats to emulate him. There is some basis for his self-belief, though not his arrogance. Murr describes Master Abraham's desk as "a magic circle which held me spellbound" (Hoffmann, 2016, p. 19) (Note 25). Initially he buffets papers about with his paws in kitten-like exuberance, but then learns to sit close while his master reads, and so learns to read himself. His method of selecting a book is catlike and comic, as he leaps up with eyes closed, not bothering to read the titles, and pulls one randomly off the shelves. "Through this mode of studying", he observes, "my mind acquired that wide-ranging flexibility, that diverse and brilliant wealth of knowledge, which posterity will admire in me" (ibid., p. 37). This unscholarly accumulation of superficial learning and his frequent relapses into instinctive behaviour set the scene for future battles between his intellectual aspirations and his animal appetites. The comic disjunction of these attributes, a hallmark of Hoffmann's style, also recurs in Sōseki's writing practice.

Like Murr, Neko has an unshakeable belief in his extraordinary abilities, and considers himself "a truly unusual cat ... with a mission demanding purely mental activity" (Sōseki, 2002, p. 178). When Kushami receives New Year cards celebrating The Year of the Cat, Neko instantly assumes they are in recognition of himself, and ridicules his master for not recognizing this obvious "fact". Neko credits himself with making his master famous, stating "It is entirely due to me that my master, hitherto a nobody, has suddenly begun to ... attract attention" (ibid., p. 20). He (Neko) is also convinced that he can "read thoughts", and, explains in quasi-scientific terms how a "beam of electricity" transmits thoughts into his "mind's eye" (ibid., p. 349). Neko acquires his literary skills differently from Murr, honing them by eavesdropping on the aesthetic discussions between his master's coterie of eccentric friends. Proficient at reading from the outset, he comments on the contents of his master's diary (ibid., pp. 14, 15, 311); a haiku in praise of cats (ibid., p. 20); and on an epitaph his master has composed (ibid., p.71). Sōseki also exploits the comic effect of the disjunction between Neko's assumption of intellectual superiority and his instinctive feline nature. As might be expected of a cat, Neko enjoys his home comforts, most of all food and frequent naps. He often exaggerates his successes, either painting himself as a hero or characterizing himself as surviving adversity. He likens his victory over a praying mantis - hardly a dangerous adversary for a cat - to the successes of "Kung Ming, that military marvel of the Shu kingdom in the third century" (ibid., p. 230). He also compares his method of descending pine trees, which he calls "pine sliding", with the legendary warrior Yotshitsune's "headlong horse charge down the cliff at Hiyodori-goe" (ibid., p. 234) 
(Note 26). The cruelty of Neko's hunting methods, and his sadistic pleasure in playing with his defenceless prey, sit ironically alongside his perceived moral superiority.

Murr, as a young cat, has much to learn, including restraint when eating, a lesson which he never fully masters. This is typified by his ode to food, beginning: "O Appetite, thy name is Tomcat" (Hoffmann, 2016, p. 29). He cannot even resist eating a herring head which he set aside to give to his mother on their first meeting. Capitulating to this basic feline instinct is comically at odds with his self-perception as a "student of psychology plumbing intellectual depths" (ibid.). Neko cannot resist food either, a character trait which conflicts with his high-flown moral pronouncements. Tempted by leftover rice-cake, he soon discovers that it has glued his jaws firmly together, and in a frantic attempt to free himself, he "pranc(es) madly all over the kitchen". However, this near-death experience, according to Neko, supposedly brings him to a realization of the following four philosophical truths: "golden opportunity makes all animals venture to do even those things they do not want to do"; "all animals can tell by instinct what is or is not good for them"; "in conditions of exceptional danger one can surpass one's normal level of achievement" and "all comfort is achieved through hardship" (Sōseki, 2002, pp. 30-31). In practice, Neko only acts on the first of these truths, and owes his survival to his master's realization that the servant woman, O-san, must act quickly to remove the rice cake from Neko's mouth. The device of ironic juxtaposition shows that both Hoffmann and Sōseki have an eye for comic buffoonery, and, furthermore, both lampoon their cat-narrators.

In Murr's autobiography, Master Abraham is the only being who escapes satire. Rather, he is subject to gentle mockery as Murr recounts how his master unhurriedly packs three nightcaps, underclothes and silken breeches, alongside a few books, when his house is in danger of burning down, (Hoffmann, 2016, p. 93). Murr's amused observations signal his understanding of and affection for the idiosyncrasies of a master who loves him. Otherwise, human shenanigans are subject to seriously scathing satire. For example, Ponto describes to Murr his adventures as a go-between for Baron Alcibiades von Wipp, carrying billets doux to and from his lovers, and facilitating illicit liaisons by guarding bedrooms and barking at danger of discovery (ibid., pp. 234-245). This comic bedroom farce mirrors tomcat sexual behaviour and ridicules aristocratic and bourgeois decadence, adultery, promiscuity and hypocrisy. Leaving kittenhood behind, Murr develops through a period which Master Abraham calls "his awkward age" (Hoffmann, 2016, p. 68). His adolescence concludes with his first experience of romantic love with a beautiful female cat named Kitty. The humour is delightful as Murr checks in Ovid's On the Art of Love to see whether he displays the appropriate lovelorn symptoms (ibid., p. 119), and writes copious love poems which he spouts out "like a person ... succumbing to terrible fits of sneezing" (ibid., p. 121). Eventually romantic fever wanes and Kitty falls in love with a huge, rough, black tomcat, a heroic figure just returned from war. Although Murr had felt "the last sparks of love ... gradually extinguished" (ibid., p. 133), he melodramatically plays the part of an abandoned husband, while secretly feeling relief at his release. Ever opportunistic, self-congratulatory and self-forgiving, he exploits the situation for the sake of appearance, challenges his rival to a duel, and ensures he completes a thick book of poems dedicated to Kitty. Sōseki does not emphasize the poetic prowess of Neko, but shows that inequality and uncontrolled sexual attraction between him and beautiful, socially superior Tortoiseshell drive this feline relationship to disaster. Romance is satirized when he overhears a conversation in which he, as a "tatty-looking tom" and "bad friend", is blamed for making Tortoiseshell ill and eventually causing her death (Sōseki, 2002, p. 51). Thus, both Hoffmann and Sōseki mock feline and human behaviour in love and lust.

Like Hoffmann, Sōseki satirizes acquisitiveness and pretentious intellectualism. Particularly ridiculed for their acquisitiveness are Kushami's neighbours, the Kanedas, who represent a growing social class of prosperous Japanese. When she meets Kushami and Metei for the first time, Mrs Kaneda introduces herself as the wife of a businessman who has been so successful that he has a large house "in the European style, with a godown" (warehouse). Contrary to her expectations, they are unimpressed, so she continues by stating that her husband is too busy "with company affairs" to meet them himself, putting on what Neko describes as a " "that ought to shift them" " face. She adds that her husband has connections with two or three companies and " "is a director of them all' " (ibid, p. 88). This undeniable proof of material success also falls on stony ground, and Mrs Kaneda cannot understand Kushami's indifference. After this encounter, Metei concludes that she "ranks a teacher on roughly the same level as a rickshaw owner", whilst Neko confirms that Kushami "only behaves most humbly toward anyone who happens to be a doctor or a professor" (ibid, pp. 97, 88). This conflict of social values is symbolized by the difference between their respective houses; Kushami's "sadly inelegant" dwelling has a "rain leak" (ibid, pp. 155, 87), whereas Neko estimates that the Kanedas' "model" kitchen is at least ten times larger than his master's (ibid, p. 103). Fittingly, Neko relishes leaving behind the marks of his "silent, muddy paws", confirmation of his successful infiltration into their home (ibid, p. 103). His satirical description of the Kanedas' 
house, the outward sign of their acquisitiveness, as "vulgar" (and) "Western", confirms that Neko dislikes avarice (ibid, p. 173). This echoes his master's opinion and, indirectly, Sōseki's.

The gullible, pretentious Kushami, who approves unreservedly of Dokusen's Zen Buddhist teachings, is also ridiculed by Neko for his inability to put these teachings into practice. His attempts to master the art of Zen meditation, which should lead him to discover his "inmost nature" through "divine enlightenment", result in failure. Grotesquely, he makes the much more mundane discovery that, when examined closely in a mirror, his facial pockmarks are "repulsive" (ibid., p. 312). Observing that Kushami cannot progress any further than studying his external self, Neko parodies a line from Pope's Essay on Man (1734)_-"the proper study of mankind is self"- to suggest the pervasiveness of self-obsession in humans (ibid., p. 316). His (Neko's) subsequent comments about self-knowledge show how much wiser he has become than his master. Furthermore, Dokusen is repeatedly satirized for his pretentious pronouncements about Buddhism, coupled with his inability to realize that he can neither express these teachings clearly, nor carry them out. Neko ironically dismisses these as "twaddle" because they include "distorted messages" and "mangled quotations" (ibid., pp. 335, 431, 436). He realizes Dokusen is deluded in believing he has achieved enlightenment, as "his feet still shuffle, earth-bound, through this world" (ibid., p. 466). As the narrative develops, the ironic gaps between the perceptions of Kushami, Dokusen and Neko imply that Neko has not only become wiser than his master, but is also more enlightened than a Zen practitioner. The comedy derives from Sōseki's characterization of Neko as the master of these masters, thus encouraging the reader to laugh at the novel's presentation of a topsy-turvy world.

As Murr matures, his world, if not his understanding, expands. This new stage of life gives Hoffmann a device to make implicit observations on student fraternities. A change in Murr's behaviour is triggered when a fellow cat, Muzius, leader of a student group (Burschenschaft), accuses him of a sluggardly life and "base Philistinism" (ibid., p. 158). Indignant, Murr commits himself to joining the student tomcat club and, after bidding farewell to Muzius with "an honest German paw-shake in the good old style" (ibid.), witnesses the huge leap that Muzius takes out of the window onto the roof next door. He reflects that all cats are innate gymnasts who need no vaulting or climbing pole (Note 27). Murr, naively describing his initiation into the student club, assures the reader that these ceremonies bear no resemblance to those of subversive secret societies (which were made illegal in 1819) (Note 28). Subversive or not, the rituals are rambunctious. Authentic German drinking songs are sung and Murr points out that his own magnificent extemporising is much admired by the fraternity. To accompany the novel, Hoffmann composed a lively parodic score of a student drinking song for Murr, which consists of meowing, screeching and caterwauling sounds that human singers are required to produce (Allroggen, 1970, pp. 84-85). At this point, Hoffmann's prose fiction is truly polyphonic. By the end of the evening, in an inebriated state, he wonders why he feels the need to use his tail "as a balancing pole" and has to be helped home (ibid., p. 160). His first hangover is the only experience which brings him loss of self-esteem: "I thought I saw that I was only an ordinary mouser! There can be nothing more depressing" (ibid., p. 173). This low point in Murr's experience foreshadows Neko's loss of self-confidence and the drunken episode which leads to his death in I Am a Cat.

Like Murr, Neko accrues a wide variety of experiences of society as he grows up and becomes more confident. Angered by a conversation in which his master is maligned by Mrs Kaneda, he decides to spy on her household, proudly affirming "I go where I like and I listen to whatever talk it interests me to hear" (Sōseki, 2002, p. 104). Neko quickly discovers that the Kanedas are also spying on his master, using Suzuki, an erstwhile associate of Kushami, to do so. Their purely materialistic motive, as Neko ascertains, is to find out if Kushami's protégé, Mizushima, would be a suitable match for their daughter, Opula. The relationship between Neko's master and his wife is also ridiculed as less than perfect. Neko observes the couple appearing so at ease together that Mrs. Kushami sits with her "majestic bum bang in her husband's face", yet, moments later, when Kushami notices the bald spot on her head, he (Kushami) openly expresses revulsion. Neko records his master's cruel judgement that his wife's baldness is a "deformity", which transgresses Japanese ideas of feminine beauty (ibid., pp. 129, 131). The adolescent Neko therefore discovers from personal observation that even that most socially valued institution, marriage, can be founded on material gain and domestic cruelty. In step with Murr, the more Neko learns about human beings, the greater is his understanding of their recurrent slippage downwards towards immoral bullying and fleshly weakness.

The causes of Neko's death are an amalgamation of despair about the human condition, loss of self-confidence, drunkeness and a Zen-like acceptance of fate. It is the culmination of a chain of events set in motion by feelings of sadness and disillusion which Neko experiences after eavesdropping on another rambling discussion between his master's friends. Their dialogue encompasses the relative merits of western and Japanese cultures; the power of the state; and the role of women in Japan. Therefrom Neko conceives that any happiness these friends might 
experience will be transient. This epiphany combines with his recent encounter with the ghost of Tomcat Murr who appears before him "piqued with curiosity" about his Japanese descendant. Realizing that he is no longer unique, Neko laps up two glasses of beer in quick succession. Inebriation brings a temporary, comic and triumphant sense of "radiant ... glory" (ibid., p. 469), but once unable to stay vertical or keep awake, he accidentally falls into a large water-filled clay pot. After desperate attempts to climb out, he resigns himself to impending death, saying "I've had quite enough, thank you, of this clutching, clawing, scratching, scraping, scrabbling, senseless struggle against nature." (ibid., p. 470). Kawana's critical explanation of the drowning argues that the cat's words are in inverted commas because they are addressed to someone who has facilitated his death and is watching him drown (Kawana, 2010, p. 17). However, Kawana's argument fails to prove convincingly that the cat's utterance is anything other than the last few words, spoken aloud, of Neko's marathon interiorized monologue. We suggest that the inverted commas signal Neko's final moments of consciousness. The novel closes with a moving expression of his transition from the material world into "the endlessness of peace" that precedes Buddhist transcendence, as he drowns his sorrows and himself (Sōseki, 2002, p. 470). The fragmented sentences and repetition of the word "thankful" through a nenbutsu chant intensify a sense of acceptance that derives from true Zen Buddhist doctrines. Porcu (2008) confirms that Neko's final words are indeed a Buddhist prayer, in which he utters the nenbutsu twice, and also expresses his gratitude to the Buddha, twice (Note 29). As the buffoonery and banality of Neko's drunkenness switches in tone to the language of philosophical acceptance, his understanding and practice of Buddhist tenets, adumbrated earlier in the novel, lends gravitas to his death. Thus, in the closing section of I Am a Cat, Sōseki makes judicious use of rapidly changing registers to present his cat-narrator's tragi-comic death.

\section{Hoffmann and Sōseki-Masters of Satire}

The sum total of Murr's adventures in Tomcat Murr constitutes a parody of a Künstlerroman (artist novel), a variation of the Bildungsroman (development novel), both familiar genres during Hoffmann's writing career. Contemporary examples are Ludwig Tieck's Franz Sternbald's Wanderings (1798) and Novalis (Friedrich von Hardenberg)'s Henry von Ofterdingen (1802), whose unworldly Romantic protagonists, respectively a painter and a poet, pass through various developmental stages and struggle with the dichotomy of self and society (Note 30). In parallel, Tomcat Murr begins with Murr's adventures as a blind newborn kitten, and ends with his death, although the planned third volume did not come to fruition. The divisions of Murr's life into periods of development are all mock-heroic. They are a neat device through which Hoffmann even-handedly critiques the tendency towards solipsism in artists and the follies of contemporary society. As Kofman points out, the pompous repetition by Murr of the beginning and ending of each stage of his life "ridicules all autobiographies of geniuses which operate in this fashion" (Kofman, 1980, p. 5).

A funeral oration is also parodied through the mouthpiece of Murr. The funeral of Muzius, who died from street-fighting injuries, offers Hoffmann excellent scope to satirize fashionable society. The gathering of cats in the cellar round his dead body reveals their collective love of food and sex, and their desire to show themselves off to each other. Over the corpse, Murr quips “Ah brother Muzius, where be now your merry gambols?", thus revealing his ostentatious aptitude for Shakespearean quotations from Hamlet (ibid., p. 212) (Note 31). His words accompany an oration of over two thousand words delivered by Tomcat Hinzmann. This cat is ironically named, giving Murr the opportunity to boast that Prime Minister Hinz von Hinzenfeldt, "so dear to the world, so greatly valued, by the name of Puss-in-Boots", is his "great and distinguished ancestor" (ibid., p. 41) (Note 32). Hinzmann's eulogy begins recognisably with "Dearly beloved brethren, gathered here to mourn ...", but switches several times mid-sentence from rhetorical praise to comic understatement: "A good and faithful husband? Ay, for he chased other little ladies only when they were younger and prettier than his wife" (ibid., p. 214). Food and drink lower the funeral from dignified mourning to flirtatious and salacious liaisons. In mock-heroic style, Murr proposes marriage to Muzius's daughter, Mina, a coupling which Kitty prevents because she knows that Mina is not Muzius's daughter, but Murr's (ibid., p 217). Murr does not explicitly comment, but this revelation shows that Muzius, whom he once idolized, put Kitty in kitten while he was encouraging Murr to duel with the soldier tomcat who broke up his (Murr's) marriage; later it transpires that Hinzmann takes his chance at the funeral to pair up with the lovely widowed Kitty (ibid., p. 230). Family deceptions seep into conversations as the funeral slips downwards from its lofty beginning into bathos, which constitutes a satire of human hypocrisy and lechery.

Murr's first-person narration bristles with literary misquotations. Indeed, Hoffmann as author often inserts his own editorial comments in brackets to chastise him for misquoting (ibid., pp. 175, 206, 218). An armoury of footnotes on literary sources in most editions of Tomcat Murr testifies to the cat's incessant plagiarisms, which are all the more comic because delivered so seriously. Whatever experiences come Murr's way, he reworks them into doggerel, and many of his orations concern food; for example, his verse eulogy of Muzius includes: 
Transfigured tom! Whene'er I eat

A tasty fish I'll think of you;

At every slice of good roast meat

I'll vow to emulate you too." (ibid., p. 229)

Describing inspiration, he again focuses on bodily, rather than spiritual expression. For example, he gives an account, taken from one of Master Abraham's old books, of the process of writing as a desire to evacuate ideas through the fingers. Although dismissing this reference to excretions as a "spiteful satire", he acknowledges that he too has a similar peculiar feeling when putting pen to paper (ibid., p. 116). Likewise, he recommends budding literary tomcats to "scatter little bits of poems here and there into their prose", which would "serve the same function as bacon in sausage ... lending the entire mixture a greasier gleam, a more delicious sweet flavour" (ibid., p. 259). Furthermore, poetry, he claims "subdues all earthly sorrows, and they say has even conquered hunger and toothache on many occasions" (ibid. p. 228). Hoffmann's parody, through the voice of Murr, of the activity of writing implies that writers would do well to keep in check their egotism and susceptibility to flattery, both of which Murr fails to do.

Petty rivalry between coteries of writers, academics and cognoscenti is also thoroughly ridiculed throughout Murr's autobiography. A character most exercised by Murr's writing talents is Professor Lothario, Master Abraham's neighbour and first owner of Ponto. As a Professor of Aesthetics, Lothario feels his superiority threatened once Ponto brings him a page of Murr's poems. To prove their provenance, he jealously watches Murr from his attic and witnesses him writing: “... sitting there at a little desk, upon which his pens and paper lay ... now dipping his pen in the ink, writing, ceasing to write, writing once again, reading his work through and purring ... with sheer delight" (ibid., p. 50). He accuses Master Abraham of teaching his cat unnatural skills, but Abraham points out his accusations are as absurd as the contemporary pedagogical fad of producing infant prodigies by teaching them as one would train dogs and monkeys (ibid., p. 49). Later Lothario confides to Abraham his deepening suspicion that Murr is a political subversive (ibid., p. 192). While Murr is eavesdropping, the Professor and a professional colleague reason that ancient academic statutes do not allow an ass to be appointed as professor, so surely that must also apply to a cat. They conclude that all they need to do in order to fend off competition is to cut off Murr's sharp claws so that he can never wound them (ibid., p. 98). That Murr characterizes himself as possessing "sharp claws" also reinforces this as a metaphor for Hoffmann's satirical rhetoric (ibid., p. 4). Clearly, Hoffmann uses Murr's feline perspective to lampoon controversial pedagogy and the politics of academia. In a similar way, Sōseki finds fertile ground for mockery in the self-important philosophical ideas on long-established Japanese cultural practices and literary forms. Neko describes Kushami's coterie as a group of "eccentrics ... gathered to keep a cat amused", denoting them as "heroic figures" and "matchless warriors" when they are nothing of the sort. He takes it as "the highest accolade that I am accepted by them" (Sōseki, 2002, p. 213).

Neko's opinion somersaults yet again, when later he finds these academics to be tedious or even laughable, describing them as a "gathering of gasbags" who keep up "endless blather, carping and flapdoodle" (ibid., p. 223). Through Neko, Sōseki uses the haiku, one of the most highly refined forms of Japanese poetry celebrated for its brevity, to satirize Mishima's lack of understanding of his cultural heritage and the ridiculous nature of the new art form which he proposes, called the "haiku-play", (ibid., p. 215). Although the haiku was then a very popular and respected poetic form, Mishima is unaware that its brevity, and its customary description of nature and the seasons, make it unsuitable as the foundation for a play. Mishima's ignorance becomes even more ludicrous, when he assumes the persona of the celebrated haiku poet, and editor of Hototogisu, Kyoshi Takahama, to declaim the haiku on which he intends to base his play:

"A crow

Is in love

With a woman in a bath" (ibid., p. 216) (Note 33).

Mishima's companions struggle with the concept that the only action in this play is a poet walking across the stage. The poet, he says, will "strike a pose for fifty seconds, to indicate how deeply he is moved by the refined haiku-like effect of the scene before him" (ibid., pp. 215-216). Although he will declaim his poem, there is no further dialogue; the woman will remain in the bath and the crow will stay in its tree. Neko senses his master's disbelief. However, Mishima remains so convinced of the validity of his new art form that he envisages Takahama himself playing the part of the poet, and devises a complex, but clearly ridiculous argument to demonstrate that the audience will realize the poet falls in love with the woman. Despite their best efforts, his friends cannot persuade 
Mishima of the absurdity of his haiku-play. Thus, in I Am a Cat, Sōseki interrogates the process and legitimacy of creating new art forms, issues which were then preoccupying Japanese intellectuals. Simultaneously he lampoons the narrow-mindedness of the world of academia, the pomposity of intellectuals and the self-importance of mediocre teachers.

As one of several forerunners to Sōseki's mastery of satire, Hoffmann employs satiric devices to lambast the showmanship and superficiality of literary salons in Tomcat Murr. Murr, in his advanced years, convinces himself that he can be both a high-minded Romantic writer and enjoy the glamour of high society. To this end, Ponto takes him to a soirée of his canine friends where he introduces him as "cat of renown" (ibid., p. 263). Only after several conversations does Murr realize that most guests are not paying any attention to his words. A snow-white greyhound, Minona, appears to be a true acolyte who can recite from his books. As he boasts about his illustrious career, he falls madly in love and offers marriage. Despite her breaking off the dialogue "mid-rapture" to talk with a young pug, Murr remains enthralled, "just as the man of La Mancha adored his Dulcinea" (ibid., p. 265). He unwittingly mocks himself by this comparison, revealing his superficial knowledge of Cervantes' knight, Don Quixote, as a comic grotesque. At the same time, Hoffmann ridicules the philistine tastes and manners of the salon. Murr's final humiliation comes while singing love songs below Minona's window, where his vocal efforts are greeted with a dowsing from a bucket of icy water. As Meyer argues, the figure of Murr "reveals the terrible banalization of poetic language". Although signing himself pretentiously as an "hommes de lettres", he fulfils this only in the letter and not in the spirit of the word (Meyer, 1968, p. 143).

In continuity with Hoffmann and a European satiric literary heritage, Sōseki also targets a broad field of human pretension and weakness displayed in Japanese culture and literary forms. His deliberately provocative aesthete, Meitei, whose Japanese name translates as Puzzling Tower, delights in subverting discussions with digressions, cleverly constructed lies and tall stories. Aware of how much Meitei likes the sound of his own voice, Neko comments "( $t$ )he dragon's head of his opening remarks has dwindled down to a snake's head of an ending," but he keeps on talking (ibid., p. 149). Similarly, fellow group member, Mishima, is ridiculed for the futility of his scientific research. His work on "The Eyeball of the Frog", is lampooned because it demands that he spends long hours in the laboratory fruitlessly "grinding glass balls" (ibid., pp. 198-199). Neko's description of this recalls Gulliver's account of the many absurd experiments in the Grand Academy of Lagado, such as "extracting sun-beams out of cucumbers" for use in inclement weather (Swift, 1963, pp. 175-176). Furthermore, the third member of the group, the poet Tofi Ochi, is satirized for two reasons. Firstly, he lacks understanding of "ancient works", and writes New-style poetry in which the imagery is so "heightened" that even he admits it is "not easy" (Soseki, 2002, pp. 41, 219). For the initial meeting of his reading group, Ochi selects a passage by the dramatist Chikamatsu Monzaemon (1653-1725), writer of bunraku (puppet plays) and kabuki plays. In Ochi's chosen passage, a boatman ferries passengers to a brothel. Ochi seems unaware of how inappropriate this is for the members of his group, as the young men who belong to it must play the parts of prostitutes. Although Ochi is supposed to have studied the piece, Neko knows more about the different types of prostitutes than he does. Secondly, Ochi is ridiculed for acting out his role as boatman so melodramatically that it is greeted with laughter, and the meeting has to be abandoned. He does not realize what a laughing-stock his reading group has become, and, undaunted, even petitions Kushami to patronize it. Neko asks, through laughter disguised as a purr, "If this were considered a success, what would failure be like?" (ibid., p. 43). Despite reading some of Ochi's poetry aloud, Kushami rejects the proliferation of imagery it contains as "beyond" him, while Mishima's puzzled response is to stutter, "I ... s... e... e" (ibid., p. 219). As a scientist, Mishima might be forgiven for not understanding such dense imagery, yet Sōseki clearly satirizes Kushami for his refusal to analyse it. To prove that he (Ochi) is not the only writer whose meaning might be obscure, Ochi refers to Sōseki's short story "A Single Night". In this merging of fact and fiction, Ochi reveals that when he spoke to Sōseki, the latter "refused to give any explanation, but even implied that ... he couldn't care less" (ibid., p. 219). Thus, Sōseki not only lambasts the group's inability to understand New-style poetry, but also turns his satire on himself when Meitei calls the author, Sōseki, "a fool" (ibid., p. 220). This exchange of views indicates that no one escapes Soseki's satire, least of all himself.

Kushami's role in these discussions is inconsistent. Although he sometimes appears wise, as shown by his initial comments on Ochi's choice of text, he is also duped by Meitei and Dokusen, the loquacious proponent of Zen Buddhism. Kushami's literary judgement is questionable as he praises "The Giant Gravitation", a story of little substance (ibid., p. 73), and his own writing abounds in ludicrous metaphors. For instance, in his poem "The Spirit of Japan" (ibid, pp. 221-222), he uses the sound of clearing phlegm from throats to evoke this spirit, which overturns a patriotic reader's expectation of inspiring rhetoric. His reference to phlegm reinforces his obsession with noses, and the grotesque use of nasal imagery which recurs - or even runs-throughout I Am a Cat. It also 
repeats the conceit, adumbrated in Tomcat Murr, which links Murr's writing with evacuating bodily fluid, and the recitation of love poems with sneezing (Hoffmann, 2016, p. 121). Neko's comment that his master's poem is "undoubtedly the masterpiece for which the anthologists have been waiting", clearly satirizes Kushami's efforts. Sōseki, mediated through the voice of his cat, satirizes teachers like Kushami, who are neither particularly creative nor adventurous. Rather, they are so set in their ways that, when they encounter new uses of language such as New-style poetry, they find them incomprehensible rather than exciting.

Lastly, through Neko's perspective, Sōseki invites the reader to re-evaluate Shakespeare's Hamlet from an unusual viewpoint, namely upside down and from a low angle. Sōseki links this act of looking with the Japanese legend of the "so-called Bridge of Heaven" (ibid., p. 226) (Note 34). When the landscape, sea, sand bar and pines are seen by bending down and looking through parted legs, a stance known as matanozoki, the landscape and its reflection appear inverted, giving the impression that the sand spit is reaching skywards, like the bridge of heaven in the legend. Thus, Sōseki ascribes a uniquely Japanese sense to the concept of topsy-turviness. Neko irreverently suggests that, were Hamlet to be viewed in this subversive way, it might be judged very differently, as a "bad" play (ibid., p. 226). Satirically, Sōseki applies this inversion to literary critics, concluding that the only way they can make any progress is to "stand on their heads" (ibid., p. 227). I Am a Cat evenhandedly directs satire at all members of the intelligentia and the rising middle classes, thus making it impossible to decide which viewpoint, register or discourse, if any, Sōseki favours. His implied philosophical position is encapsulated in Neko's conclusion that "mankind's value judgements turn somersaults and cartwheels for no conceivable reason" (ibid., p. 226).

\section{Conclusions}

Both Hoffmann and Sōseki were passionate readers and prolific writers. Hoffmann read and drew upon Shakespeare, Cervantes, Swift, Sterne and Walter Scott, and immersed himself deeply in his own German literary heritage. His own oeuvre, a substantial part of which was translated into English and French by the 1830s, influenced writers as diverse as Charles Baudelaire, Edgar Allan Poe, Fyodor Dostoevsky, Thomas Mann and Angela Carter. We add Sōseki to this roll-call. As our article shows, Sōseki, like Hoffmann, drew on a multitude of literary precursors and his Japanese heritage, creatively reworking many literary strands. There is no better illustration of Sōseki's obsession with books than Teisuke Fujishiro's visit to his room in London in 1902, which he (Sōseki) was unable to vacate for the return voyage with him to Japan because of piles of book in every inch of available space (Nathan, 2018, p. 70) (Note 35). As we have argued, Sōseki's life-long friendship, both with Fujishiro, fellow Monbushō scholar, and German professor, Raphael von Koeber, suggests that Hoffmann's work was known to all three. Furthermore, as proven, the historical and cultural context of the late-nineteenth and early-twentieth century attests to a massive influx of western literature into Japan which was available to all readers, not only those inhabiting academia. Sōseki explicitly refers to Tomcat Murr in the third volume of $I \mathrm{Am}$ a Cat, published in novel form in 1907, but we hypothesize that all three volumes published from 1905 onwards, show the integral influence of Murr on Neko, Soseki's unnamed cat. Hoffmann's Tomcat Murr and Sōseki's I Am a Cat are hybrid novels which comprise many intertextual borrowings, both literary and social. These two distinctively polyphonic novels are amalgamations of many precursory literary texts. Therefore, while Sterne's Tristram Shandy, Gentleman and Swift's Gulliver's Travels obviously shaped Sōseki's I Am a Cat, there is no reason to exclude Hoffmann's Tomcat Murr from sharing an influence upon this Japanese novel.

\section{Acknowledgements}

We are indebted to several standard translations of German and Japanese texts. We would also like to thank Nora Crook, international scholar in the field of Shelley studies, who sowed the seed of an idea for our article after she lectured in Japan.

\section{References}

Aldridge, A. O. (2008). Ludic Prose from Lawrence Sterne to Carlos Fuentes. In G. G. Gillespie, M. Engel \& B. Dieterle (Eds.), Romantic Prose Fiction (pp. 655-663). Amsterdam: Philadelphia. https://doi.org/10.1075/chlel.xxiii.42ald

Allroggen von, G. (1970). E. T. A. Hoffmanns Kompositionen: Ein chronologisch-thematisches Verzeichnis seiner musikalischen Werke mit einer Einfuhrung. Regensburg: Gustav-Bosse-Verlag.

Barasch, F. K. (1968). Introduction to A History of Caricature and the Grotesque (1788) by Thomas Wright (pp. 7-57). New York: Ungar.

Beauchamp, F. (2019). The Tale of the Heike and Japan's Cultural Pivot to the Art of War. Asian Literature in the Humanities and the Social Sciences, 24(3). Retrieved January 20, 2021, from 
https://www.asianstudio.org/publications/eaa/archives/the-tale-of-the-heike-and-japanese-cultural-pivot-to-t he-art-of-war/

Burwick, F. (1987). The Haunted Eye: Perception and the Grotesque in English and German Romanticism. Heidelberg: Carl Winter UP.

Clark, P. H. (undated). The Creation of the Modern Japanese Language in Meiji-Era. Retrieved August 3, 2020, from https://www.japanpitt.pitt.edu/essays-and-articles/language/creation-modern-japanese-language-meiji-era

Clason, C. R. (1992). The Vignettes in E.T.A. Hoffmann's Kater Murr: Portraits of Artists and Lovers. German Studies Review, 15(3), 493-503. https://doi.org/10.2307/1430364

Cockerill, H. (2007-8). Four Translations of Crime and Punishment. The Dostoevsky Journal, 8-9, 53-62. https://doi.org/10.1163/23752122-00801004

Davisson, Z. (2017). Kaibyō: The Supernatural Cats of Japan. Seattle: Chin Music Press and Mercuria Press.

Fujii, J. A. (1989). Contesting the Meiji Subject: Sōseki's Neko Reconsidered. Harvard Journal of Asiatic Studies, 49(2), 553-574. https://doi.org/10.2307/2719263

Gallimore, D. (2016). Tsubouchi Shoyo and the Beauty of Shakespeare Translation in 1900s Japan. Multicultural Shakespeare: Translation, Appropriation and Performance, $13(28)$. https://doi.org/10.1515/mstap-2016-0006

Gordon, A. (1991). Making News Graphic. In Labor and Imperial Democracy in Prewar Japan. Berkeley: California UP. https://doi.org/10.1525/9780520913301

Hamano, O. (1973). Sōseki no Neko to Hofuman no Neko to. In Y. Seiichi (Ed.), Natsume Sōseki Zenshu, Bekkan. Tokyo: Chikuma Shobō.

Hoffmann, E. T. A. (1985). Klein Zaches Genannt Zinnober (1819). In Ernst Theodor Amadeus Hoffmann: Collected Works (Vol. 3). Frankfurt: Steineke, Deutsche Klassiker Verlag.

Hoffmann, E. T. A. (1993a). Fantasiestücke in Callots Manier (1814). In Ernst Theodor Amade Hoffmann: Collected Works (Vol. 2/1). Frankfurt: Steineke, Deutsche Klassiker Verlag.

Hoffmann, E. T. A. (1993b). Kreisleriana (1815). In Ernst Theodor Amadeus Hoffmann: Collected Works (Vol. 2/1). Frankfurt: Steineke, Deutsche Klassiker Verlag.

Hoffmann, E. T. A. (1993c). Die Abenteuer Der Sylvester-Nacht (1815). In Ernst Theodor Amadeus Hoffmann: Collected Works (Vol. 2/1). Frankfurt: Steineke, Deutsche Klassiker Verlag.

Hoffmann, E. T. A. (2001). Das Fräulein von Scuderi (1820). In Ernst Theodor Amadeus Hoffmann: Collected Works (Vol. 4). Frankfurt: Steineke, Deutsche Klassiker Verlag.

Hoffmann, E. T. A. (2003). Fragment of a Humorous Essay (1796). In Ernst Theodor Amadeus Hoffmann: Collected Works (Vol. 1). Frankfurt: Steineke, Deutsche Klassiker Verlag.

Hoffmann, E. T. A. (2004). Meister Floh (1822). In Ernst Theodor Amadeus Hoffmann: Collected Works (Vol. 6). Frankfurt: Steineke, Deutsche Klassiker Verlag.

Hoffmann, E. T. A. (2016). Lebensansichten des Katers Murr (1819-1821). Loschberg: Jazzybee Verlag.

Ishikura, W. (2006). The Reception and Translation of Wordsworth in Japan. CLCWeb: Comparative Literature and Culture, 8(2), 1-10. https://doi.org/10.7771/1481-4374.1309

Jacobowitz, S. (2009). The Discourse of Noses in Natsume Sōseki's I Am a Cat. Association for Japanese Literary Studies, 10, 45-55.

Jenkins, M. E. (2004). Trans. The History of Japan's Educational Development: What Implications can be Drawn for Developing Countries Today. Tokyo: Institute for International Cooperation, Japan International Cooperation Agency. Retrieved February 11, 2021, from http://www.jica.go.jp/english

Katō, S. (1997). A History of Japanese Literature from the Man'yōshū to Modern Times (D. Sanderson Trans.). London: Routledge. https://doi.org/10.4324/9780203462461

Kawana, S. (2010). A Narrative Game of Cat and Mouse: Parody, Deception, and Fictional Whodunit in Natsume Sōseki's Wagahai Wa Neko Dearu. Journal of Modern Literature, 33(4), 1-20. https://doi.org/10.2979/jml.2010.33.4.1

Kayser, W. (1966). The Grotesque in Art and Literature (U. Weisstein Trans.). New York: McGraw-Hill. 
Keene, D. (1998). Dawn to the West: Japanese Literature of the Modern Era. New York: Columbia UP.

Kofman, S. (1980). No Longer Full-Fledged Autobiogriffies. SubStance, 9(4), 3-22. https://doi.org/10.2307/3684037

Kuramoto, K. (2006). Don Quixote and Natsume Sōseki. J. Cullen (Trans.). Review of Japanese Culture and Society, 18, 57-74.

Lippit, N. M. (1977). Natsume Sōseki on Poe. Comparative Literature Studies, 14(1), 30-37.

Lozerand, E. (2013). The Rise of Criticism (1886-1889) Sohō, Hanpō, Ōnishi, Ōgai. Cipango-French Journal of Japanese Studies, 2, 1-33. https://doi.org/10.4000/cjs.289

Marcus, M. (2009). Reflections in a Glass Door: Memory and Melancholy in the Personal Writings of Natsume Sōseki. Honolulu: Hawaii UP. https://doi.org/10.21313/hawaii/9780824833060.001.0001

Meyer, H. (1968). E.T.A. Hoffmann: Life and Opinions of Tomcat Murr. In The Poetics of Quotation in the European Novel (pp. 125-147). Princeton: Princeton UP. https://doi.org/10.1515/9781400875887-007

Milasi, L. (2009). A Meiji Writer's Outlook on Chinese Literature: The case of Mori Ōgai. Phoenix in domo Foscari: The Online Journal of Oriental Studies, 2, 253-291.

Miller, S. (2018). The Nine and More Lives of Poe's Black Cat in Japanese. Kyoto Poe Conference. Retrieved February 12, 2021, from https://www.academia.edu/37594534/The_Nine_and_More_Lives_of_Poes_Black_Cat_in_Japanese

Mizukawa T. (2007). Natsume Sōseki and Shin Buddhism. The Eastern Buddhist New Series, 38(1/2), 145-179.

Nakagawa, T. (2014). Naming the Unnamable: Monstrosity and Personification in the First Japanese Translation of Frankenstein and its Illustrations. In A. Watson \& N. Miyamoto Alvey (Eds.), Poetica: International Journal of Linguistic-Literary Studies (Romantic Connections Issue, pp. 82, 95-113). Tokyo: Maruzen-Yushodo.

Nakai, Y. (1978). Mori Ōgai's German Trilogy: A Japanese Parody of Les Contes d'Hoffmann. Harvard Journal of Asiatic Studies, 38(2) 381-422. https://doi.org/10.2307/2718905

Napier, S. (2015). Introduction to Ten Nights'Dreaming and The Cat's Grave. New York: Dover Publications.

Nathan, J. (2018). Sōseki: Modern Japan's Greatest Novelist. New York: Columbia UP. https://doi.org/10.7312/nath17142

Ōgai, M. (1994). Youth and Other Stories (J. T. Rimer Ed.). Honolulu: Hawaii UP.

Otaki, N. (Ed.). (2014). Modern Japan and France: Adoration, Encounter and Interaction. Tokyo: National Diet Library. Retrieved August 25, 2020, from https://www.ndl.go.jp/france/en/part2/s1_2.html

Poch, D. (2019). Translation, Human Emotion, and the Bildungsroman in Meiji Japan: Narrating Passion and Spiritual Love in the Novel Karyū Shunwa. Japanese Language and Literature: Journal of the American Association of Teachers of Japanese, 53(1), 63-93. https://doi.org/10.5195/j11.2019.56

Poe, E.A. (1993). Tales of Mystery and Imagination. Ware: Wordsworth.

Porcu, E. (2008). Pure Land Buddhism in Modern Japanese Culture. Leiden: E. J. Brill. https://doi.org/10.1163/ej.9789004164710.i-263

Rimer, T. J. (1975). Mori Ōgai. Boston: Twayne Publishers.

Sahlin, J. C. (Ed. \& Trans.) (1977). Selected Letters of E.T.A. Hoffmann. Chicago: Chicago UP.

Schmidt, R. (2001). Narration - Malerei - Musik: Mediale Interferenz am Beispiel E.T.A. Hoffmanns. Kulture-Poetik Zeitschrift für Kulturgeschickliche Literaturwissenschaft, 1(2), 182-213.

Scott, W. (1827). On the Supernatural in Fictitious Composition; and Particularly on the Works of Ernest, Theodore, William Hoffman. London Foreign Quarterly Review, 60-98

Scullion, V., \& Treby, M. (2013). Repressive Politics and Satire in E.T.A. Hoffmann's Fairy Tales, Little Zaches Acclaimed as Zinnober and Master Flea. Journal of Politics and Law, 6(1), 133-145. https://doi.org/10.5539/jpl.v6n3p133

Shelley, M. (1993). Frankenstein (1818). Ware: Wordsworth.

Sōseki, N. (2002). I Am a Cat (1905-1907) (A. Ito \& G. Wilson Trans.). Boston: Tuttle.

Sōseki, N. (2004). My Individualism and the Philosophical Foundations of Literature (1914 and 1904). Boston: 
Tuttle.

Sōseki, N. (2009). Theory of Literature and Other Critical Writings (1907) (M. K. Bourdaghs, A. Ueda \& J. A. Murphy Eds.). New York: Columbia UP.

Sōseki, N. (2015). Ten Nights Dreaming and The Cat's Grave (M. Treyvaud Trans.). New York: Dover Publications.

Sterne, L. (2009). The Life and Opinions of Tristram Shandy, Gentleman (1759-1767). Oxford: Oxford UP. https://doi.org/10.1093/oseo/instance.00167759

Swift, J. (1963). Swift: Gulliver's Travels and Selected Writings in Verse and Prose. London: Nonesuch.

Thompson, S. (1955-1958). Motif-Index of Folk-Literature: A Classification of Narrative Elements in Folktales, Ballads, Myths, Fables, Medieval Romances, Exempla Fabliaux, Jest-Books, and Local Legends. Bloomington: Indiana UP.

Tieck, L. (2012). Franz Sternbalds Wanderungen: Eine altdeutsche Geschichte. Hamburg: Tredition Classics.

Tieck, L. (2015). Ludwig Tiecks Schriften (Vol 4. Phantasus I, 1812. Introduction by A. W. Schlegel). Berlin: Reimer (1828). Retrieved October 9, 2019, from Project Gutenberg eBook \#50480, gutenberg.org/

Treat, J. W. (2018). The Rise and Fall of Modern Japanese Literature. Chicago: Chicago UP. https://doi.org/10.7208/chicago/9780226545271.001.0001

Yoshida, R. (1968). Wagahai wa Neko de Aru Ron: Soseki no “Neko” to Hofuman no "Neko”. Tokyo: Keisō Shobō.

Yoshio, H. (2012). Envisioning Women Writers: Female Authorship and the Cultures of Publishing and Translation in Early 20th Century Japan. PhD dissertation. Columbia University.

Yuzuru, M. (Trans.) (2001). Classic Haiku: A Master’s Selection. Boston: Tuttle Publishing.

\section{Notes}

Note 1. Sōseki's given name was Natsume Kinnosuke. He took on the pen name Sōseki in 1887 when he met Masaoka Shiki, who encouraged him to write haiku.

Note 2. In comparing Walter Scott with Laurence Sterne and Jonathan Swift, Hoffmann writes that "he lacks the radiance of deep humour that flashes from Sterne's and Swift's work" (Sahlin, 177, p. 305).

Note 3. Napier argues that the dream images in Sōseki's Ten Nights Dreaming (1908) "relate to the deep transitions convulsing his (Sōseki's) community as a whole", caused by the challenge of western modernity to Japanese culture during the Meiji period (Napier, 2015, p. 7). In the seventh dream, the narrator voyages towards a destination unknown even to the crew. He decides to commit suicide, but then regrets jumping overboard. His perceptions may signify that Sōseki cannot live without Japanese culture, even if it is heading in a direction that he finds disturbing. The narrator's description of the black smoke belching from the ship may have been inspired by Commodore Matthew Perry's so-called "black ships", the Japanese term for his steam ships, the like of which had never been seen before their arrival in 1853 .

Note 4. Lectures entitled "The Philosophical Foundations of Literature", which Sōseki gave as a Professor at Tokyo University were published in 1904. Here he advocates synthesizing the realism, so prevalent in western literature, with the philosophical Japanese preoccupation with goodness, beauty and sublimity. See Sōseki, 2004. He also published Theory of Literature (1907), one of the earliest critical works on literature in Japanese.

Note 5. Gordon explains that, "(w)hereas 2,000 to 5,000 copies might have been made of a traditional woodblock print of this era, each issue of the Japanese Graphic (and its competitors) boasted print runs of 40,000 to 50,000 copies, offering 20 to 50 photographs and illustrations of varied sizes and types per issue." The Customs Graphic (Fūzoku Gahō) founded in 1889, and the Japanese Graphic (Tōyō Gahō) founded in 1903, typify the explosion of print magazines and books modelled on European or American predecessors at the turn of the century (Gordon, 1991, ch. 1).

Note 6. The Japanese translation of Frankenstein, given the title The New Creator, appeared in Kuni no Motoi, 1(3), 1889.

Note 7. Edward Bulwer-Lytton's Ernest Maltravers (1837), and its sequel, Alice (1838), were translated by Oda Jun'ichirō (1851-1919) as Karyū Shunwa (A Springtime Tale of Blossoms and Willows) in 1879. See Poch, 2019. Typically, as early translations, they were not literal, and omitted passages thought not to be intelligible to 
a Japanese audience (Keene, 1998. pp. 65-68). A "synopsis-translation" by Tsubouchi Shōyō (1859-1935) of Bulwer-Lytton's Rienzi (1835) followed in 1885 (ibid., pp. 96-97). Tokutomi Soho (1863-1957) refers to Wordsworth in his 1888 essay, Shin Nihon no Shijin (The Poet of the New Japan). Doppo Kinikida (1871-1908) included a translation of part of Wordsworth's Tintern Abbey in his novel Koharu (1900). See Ishikura, 2006. In 1893 Sōseki published his essay "Nature as Viewed by the English Poets", which focuses on Wordsworth and Robert Burns (Keene, 1998, p. 307). In 1892-1893, Uchida Roan (1868-1929) published his translation of Dostoyevsky's Crime and Punishment (1866). See Cockerill, 2008-2009. Also in the 1890s, Shōyō published translations of the first scenes of Shakespeare's Hamlet and Macbeth, which were not intended for performance. By 1913, Shōyō had translated all of Hamlet, Romeo and Juliet, Othello, King Lear and Julius Caesar using language appropriate for the stage. See Gallimore, 2016. Literary criticism also burgeoned in Japan in the 1880s. See Lozerand, 2013.

Note 8. A partial translation of Brontë's Jane Eyre (1847) by Mizutani Futō (1858-1943), entitled Risō no Kajin (Ideal Woman), appeared in 1896. Shimamura Hōgetsu's adapted translation of Grant Allen's bestselling New Woman novel, The Woman Who Did (1893), was serialized in the newspaper Yomiuri Shimbun, with the title Sono Onna (That Woman, 1901) (Yoshio, 2012, pp. 30, 73).

Note 9. The anthology Kaichoon (The Sound of the Tide, 1905), compiled by Ueda Bin (1874-1916), includes translations of poems by Charles Baudelaire, Stéphane Mallarmé and Paul Verlaine. Retrieved August 25, 2020 from http://japan_literature.enacademic.com/149/KAICHOON

Note 10. According to Keene, Uchida Roan also introduced Émile Zola to the Japanese (Keene, 1998, p. 224). In 1889, Mori Ōgai wrote two essays on Zola: "Literary theories derived from medicine" and "The recent theories on the novel" (Milasi, 2009, p. 291). Naiga Kafū (1879-1959) published a partial translation of Zola's Nais Micoulin (1884) in 1902 and a summary translation of Nana (1880) in 1903 (Keene, 1998, p. 395).

Note 11. Mori Ōgai's contributions to the journals The Weir, Vestiges and Remarkable Notes are extensive. See Rimer's summary, 1975, pp. 24-27. During his stay in Germany, Mori Ōgai saw a performance of Albert Lorzing's version of Hoffmann's opera, Undine, and annotated his own copy of Lorzing's libretto, now in Tokyo University Library (Nakai, 1978, p. 398, note. 14). Nakai interprets Mori Ōgai's first Japanese trilogy of stories, Youth and Other Stories (1890-1891) as parodies of Jacques Offenbach's version of Hoffmann's tales (Nakai, 1978, p. 389).

Note 12. See Miller's conference paper on Poe's The Black Cat (2018) for insights into his debt to Hoffmann and the transmission of themes and stories from author to author.

Note 13. Sōseki wrote a literary portrait of Koeber, published in the Asahi Shimbun newspaper in July 1911, where he states: "I recall having seen him, long ago, taking out the collected works of Edgar Allan Poe from the University library. He'd mentioned being an avid reader of Poe and E.T.A. Hoffmann." Sōseki also describes him quoting the famous line "Never more" from Poe's poem, "The Raven" (Marcus, 2009, p. 165).

Note 14. Polyphony is a literary critical term borrowed from the field of music, in which it means multi-stranded choral, instrumental or orchestral sounds. When applied to literature, it refers to the textual interweaving of multiple registers and discourses.

Note 15. Hoffmann's use of a humanized animal in Tomcat Murr to satirize artistic and philistine pretensions is anticipated in a Kreisleriana sketch, "Report of an Educated Young Man" (1815). The young "man", named Milo, is a concert pianist, but also an ape. Through Milo, Hoffmann mocks a so-called cultured élite, which does not know good music from bad. Jonathan Swift's device of inverting the status of Yahoos (apes) and Houyhnhnms (horses) in order to satirize perceived human superiority in Gulliver's Travels (1726) was probably an influence on Hoffmann.

Note 16. For an account of teaching as a sacred profession and its social status in the early years of Japan's state education system, see Jenkins, 2004, p. 20.

Note 17. Treat defines genbun'itchi as "the modern, vernacularized literary language" which had become a matter of government concern at the time when Sōseki was writing I Am a Cat (Treat, 2018, p. 87). In March 1900, the Genbun'itchi Society was tasked with promoting this colloquial style and disseminating it through written contributions to newspapers and magazines.

Note 18. In Aarne-Thompson-Uther's catalogue of folktales, Puss-in-Boots is categorized as ATU 545B, a subsection of ATU 545, in the section entitled "Services of Helpful Animals".

Note 19. The Japanese attribution of viciousness to cats may stem from Japanese folklore which characterizes 
the snake and the cat as the only creatures who did not cry when Buddha died. In brief, when a domestic cat grows old, Japanese legends say it turns into a bakeneko, a shape-shifting cat, often depicted on its hind-legs dancing with a towel on its head; or it may transform into a nekomata, which develops a split tail and grows huge; or it may transform into a prostitute which eats its clients; or it may arrive in a flaming cart from the sky to steal and eat corpses, and so on. Benign supernatural cats are fewer in number, including gotoku neko, the trivet cat, which keeps the fire in the hearth going and maneki neko, the beckoning cat that brings good luck (Davisson, 2017, p. 16).

Note 20. Sōseki's influential essay on Tristram Shandy was published in the journal Koko Bungaku. See Kuramoto, 2006.

Note 21. Sōseki's title, Wagahai wa Neko de Aru, ridicules a form of speechmaking called enzetsu invented by Fukuzawa Yukichi in 1874 in order to raise the tone of speech-makers. Treat explains that the then prime minister, Ōkuma Shigenobu, employed enzetsu by adding "the presumptuous first-person singular pronoun wagahai at the start of his illocutions (sic) and ending his sentences with the equally pompous copula de aru $n$ de aru. Sōseki's ridicule of enzetsu is found throughout the novel" (Treat, 2018, p. 76).

Note 22. See Barasch's Introduction to A History of Caricature in Literature and Art (1788) by Thomas Wright, which summarizes Flögel's theories of the grotesque (Barasch, 1968, pp. 49-51).

Note 23. Burwick focuses on the use of the grotesque in Hoffmann's The Sandman (1816), but affirms that the theme is systemic throughout Hoffmann's work (Burwick, 1987, pp. 258-266).

Note 24. In his essay on Tristram Shandy, Sōseki cites the opinion of Thomas Carlyle (1795-1881) that Sterne and Cervantes "were the two great humorists of the world" (quoted in Kuramoto, 2006). Both satirists influenced Hoffmann and Sōseki's writing.

Note 25. The motif of the circle to characterize the cat-narrator, Tomcat Murr, and his world connects him with the other protagonist in Tomcat Murr, Johannes Kreisler, whose surname means circler, and who "circulates in circles", as he progresses through life (Hoffmann, 2016, p. 42).

Note 26. Yoshitsune (1159-1189) is "probably the single most famous man in all of premodern Japanese history." One of his most celebrated exploits, commemorated in Utogawa Hiroshige's series of woodblock prints, The Life of Yoshitsune (1832-1834), was to lead his cavalry down the Hiyodori Pass, the ravine at Ichinotani, to carry out a surprise attack. "The slope was so steep that those behind found the front of their stirrups bumping against the helmet of the rider ahead". See Beauchamp, 2019. Sōseki's contemporary readers would have immediately recognised the irony of cat-narrator, Neko, arrogantly comparing his pine sliding to Yoshitsune's horse charge.

Note 27. The allusion here is probably to Friedrich Ludwig Jahn who founded the student gymnastic movement in Berlin in 1810, whom Hoffmann also satirizes through the character Professor Mosch Terpin in his fairy tale, Little Zaches, Acclaimed as Zinnober (1818-1819) (Hoffmann, 1985, vol. 3, p. 552).

Note 28. The restoration of Prussian rule after the defeat of Napoleon's forces brought with it the Carlsbad Decrees of 1819 which censored the press, installed inspectors in the universities, banned student fraternities and outlawed any activity judged to be unpatriotic. In 1818, Hoffmann, as a high-ranking judge in the Supreme Court of Justice in Berlin, was appointed to the reactionary commission which enforced these laws. He defended Friedrich Ludwig Jahn when he was arrested as an enemy of the state. See Scullion and Treby, 2013, p. 134.

Note 29. Porcu cites the 1961 translation of I Am a Cat by Katsue Shibata and Motonari Kai, which is closer to Sōseki's original Japanese than the translation we have used by Aiko Ito and Graeme Wilson. She questions the inaccurate and non-Buddhist insertion of Ito and Wilson's translated phrase, "I am dying, Egypt, dying", just before the nenbutso chant (Sōseki, 2002, p. 638). In the Shibata and Kari translation, the nenbutso is rendered as the twice repeated chant "Save us merciful Buddha!". Then the final words, "Gracious blessings", show the cat-narrator, Neko, thanking the Buddha for his compassion. Porcu concludes that closing the novel with this chant demonstrates Sōseki's dependence on ideas derived from the tradition of Pure Land Buddhism (Porcu, 2008, p. 113). Mizukawa also cites this chant, calling it a nembutso, but associating it with Shin Buddhism (Mizukawa, 2007, p. 154).

Note 30. Satirizing the Romantic artist and parodying the Künstlerroman are recurring preoccupations in Hoffmann's work. As one example, Schmidt relates the tribulations of the first person narrator, Erasmus Spikher, in Hoffmann's New Year's Eve Adventure (1815) to Franz Sternbald in Tieck's Franz Sternbald's Wanderings (1798). She analyses a scene set in an Italian inn, where aspirational artist, Spikher, meets with fellow painters, as "burlesquing" the gathering of painters in an Italian garden in Wanderings (Schmidt, 2001, p. 198; Hoffmann, 
1993c, vol. 2/1, p. 342).

Note 31. Hoffmann, refracted through cat-narrator Tomcat Murr, quotes from August Schlegel's contemporary translation of Shakespeare's Hamlet, V. i, the scene in which Hamlet addresses Yorick's skull.

Note 32. The surname Hinze comes from Ludwig Tieck's satiric play, Puss-in-Boots (1797). Tieck, a personal acquaintance of Hoffmann, dramatized the fairy tale for inclusion in the first edition of Phantasus (1811), a collection of fairy tales which Hoffmann describes as "magnificent" (Sahlin, 1977, p. 300). Tieck's version predates the temporary inclusion of Puss-in-Boots in the first edition of the Grimm Brothers' fairy-tale collection, Children's and Household Tales (1812).

Note 33. Miura Yuzuru translates Takahama's haiku as

"A woman

Taking a bath in a tub

Is coveted by a crow". See Yuzuru, 2001, p. 52.

Note 34. In Japanese mythology, Izanagi (He Who Invites) and Izanami (She Who Invites) stand on the floating bridge of heaven and stir the primeval ocean with a heavily jewelled spear, to create the first land mass. Izanagi and Izanami thus created Japan's many islands, and legend has it that their bridge to heaven is represented by the 3-metre-long isthmus, Ama-no-hashidate, at Miyazu Bay, in Japan's northern Kyoto Prefecture. For images of the location and the matanozoki stance, see http://www.viewland.jp/en/hiryukan/Retrieved January 20, 2021.

Note 35. Fellow-boarder, Watanabe Shunkei, describes Soseki's room as "absolutely crammed with books — piled onto his desk, on the floor, on the mantelpiece—everywhere!” (Marcus, 2009, p. 33).

\section{Copyrights}

Copyright for this article is retained by the author, with first publication rights granted to the journal.

This is an open-access article distributed under the terms and conditions of the Creative Commons Attribution license (http://creativecommons.org/licenses/by/4.0/). 